\title{
Emended description of the species Lampropedia hyalina
}

\author{
Natuschka Lee, ${ }^{1}$ Carmela Maria Cellamare, ${ }^{2}$ Cristiano Bastianutti, ${ }^{2}$ \\ Ramon Rosselló-Mora, ${ }^{3}$ Peter Kämpfer, ${ }^{4}$ Wolfgang Ludwig, ${ }^{1}$ \\ Karl Heinz Schleifer ${ }^{1}$ and Loredana Stante ${ }^{2}$ \\ ${ }^{1}$ Lehrstuhl für Mikrobiologie, TU München, Am Hochanger 4, D-85350 Freising, Germany \\ ${ }^{2} E N E A$, Sezione Gestione Risorse Idriche, Via Martiri di Monte Sole, 4, I-40129 Bologna, Italy \\ ${ }^{3}$ Grup d'Oceanografia Interdisciplinari Institut Mediterrani d'Estudis Avançats (CSIC-UIB), \\ C/Miquel Marqués 21, E-07190 Esporles Mallorca, Spain \\ ${ }^{4}$ Institut für Angewandte Mikrobiologie, Universität Giessen, Heinrich-Buff-Ring 26-32 (IFZ), \\ D-35392 Giessen, Germany
}

Correspondence Natuschka Lee leen@mikro.biologie. tu-muenchen.de
Three Lampropedia hyalina strains from different habitats were compared by phenotypic, chemotaxonomic and molecular characteristics. All strains form coccoid cells and have been reported to grow as square tablets of eight to 64 cells. However, two of these strains (ATCC $11041^{\top}$ and ATCC 43383) have apparently lost this ability, and the third strain may temporarily lose this capacity under certain cultivation conditions. The three strains showed only minor differences in metabolic characteristics: the main significant physiological difference was the ability to accumulate polyphosphate under alternating anaerobic-aerobic conditions found for DSM 15336. The three strains showed high similarity in fatty acid composition and only slight differences in the $\mathrm{G}+\mathrm{C}$ content (63-67 mol\%) and DNA-DNA reassociation (90-95\% relatedness). Comparative 16S rRNA gene sequence analyses on these three strains and three Lampropedia hyalina 16S rRNA gene sequences deposited at NCBI showed that they are all very similar ( $>98.8 \%$ ) and that they form a distinct group among the 'Betaproteobacteria', showing between 94.6 and $93 \% 16 \mathrm{~S}$ rRNA gene similarity to members of various genera such as Acidovorax, Aquaspirillum, Brachymonas, Comamonas, Delftia and Xenophilus. Fluorescent in situ hybridization with oligonucleotide probes targeting betaproteobacteria on the 16S rRNA and 23S rRNA gene level further supported the conclusion that all investigated strains are members of the 'Betaproteobacteria'. Two oligonucleotide probes were designed and successfully applied for culture-independent identification of Lampropedia hyalina by means of fluorescent in situ hybridization.
A specimen of the square-tablet-forming, coccoid, heterotrophic genus Lampropedia was described for the first time in 1886 by Schroeter in polluted water samples (Schroeter, 1886). Since then, cells similar to Schroeter's description have been observed on several occasions in aquatic systems rich in organic material, rumen or the intestinal system in some animals (Murray, 1984). Our knowledge of this genus is limited, since it is based mainly on the phenotypic

Published online ahead of print on 23 March 2004 as DOI 10.1099/ ijs.0.02885-0.

Abbreviation: GTA, green top agar.

The GenBank/EMBL/DDBJ accession numbers for the 16S rRNA gene sequences of Lampropedia hyalina strains DSM 15336, ATCC $11041^{\top}$ and ATCC 43383 are respectively AY291119, AY291120 and AY291121. characteristics of one species, Lampropedia hyalina, which is represented by four strains deposited at the ATCC. However, this collection demands further investigation, since the type strain ATCC $11041^{\mathrm{T}}$ has apparently lost the tablet-forming ability and grows instead as single coccoid cells. Murray (1984) thus stated that a neotype strain might have to be declared. Recently, Stante et al. (1997) isolated a tablet-forming Lampropedia-like specimen (DSM 15336) from activated sludge laboratory plants treating dairy and piggery wastewater that were operated as an enhanced biological phosphorus-removing system. This strain differs in at least one metabolic aspect from the Lampropedia hyalina type strain, i.e. the ability to accumulate polyphosphate under alternating aerobic-anaerobic conditions (Stante et al., 1997). The aim of our study was to compare the phenotypic, chemotaxonomic and molecular characteristics of this isolate with two Lampropedia hyalina strains 
from the ATCC isolated from other environments and to design specific oligonucleotide probes for fluorescent in situ hybridization for culture-independent identification of Lampropedia hyalina.

The following strains were used: Lampropedia hyalina ATCC $11041^{\mathrm{T}}\left(=\right.$ CCUG $48573^{\mathrm{T}}=$ DSM $\left.16112^{\mathrm{T}}\right)$, isolated in 1966 by E. G. Pringsheim from liquid manure from a dairy farm yard; Lampropedia hyalina ATCC 43383 (=CCUG 48574), isolated by J. Kirchner from the rumen of a fistulated heifer (Hungate, 1966); and Lampropedia sp. DSM 15336 (=CCUG 48575), isolated by Stante et al. (1997) from activated sludge. For standard cultivations, all three strains were grown at $\mathrm{pH} 7 \cdot 2$ and at $25^{\circ} \mathrm{C}$ on a medium containing moderate amounts of peptone, acetate, yeast extract and soil extract [ATCC culture medium 32; green top agar (GTA)] or on a modified version of this medium made by replacing the soil extract with filtered and sterilized effluent from a diary wastewater treatment plant (Stante et al., 1997). Fresh and stained cells (Gram, Neisser, Sudan black B and Nile blue A) were viewed by light and fluorescence microscopy, respectively, as described by Stante et al. (1997). All three strains are unpigmented and produce white colonies with internal refractile structures on GTA plates at $25^{\circ} \mathrm{C}$. Strains ATCC $11041^{\mathrm{T}}$ and ATCC 43383 have distinctive, round colonies, whereas strain DSM 15336 produces round colonies with partly square borders. Strain ATCC 43383 produces slimy, glossy, transparent colonies, whereas strains ATCC $11041^{\mathrm{T}}$ and DSM 15336 produce dry, matt, transparent colonies. Growth was usually obtained after 1-3 days at $25^{\circ} \mathrm{C}$. All three investigated strains have been reported to be Gram-negative, coccoid cells $(1 \cdot 0-1 \cdot 5 \times 1 \cdot 0-2 \cdot 5 \mu \mathrm{m})$, able to produce square tablets of eight to 64 cells (Murray, 1984; Stante et al., 1997). However, both ATCC strains have apparently lost this ability, despite strict cultivation under the conditions recommended by the initial discoverers. Strain ATCC $11041^{\mathrm{T}}$ was already reported to have lost this ability in 1963 (Murray, 1963), whereas our study is the first to report that ATCC 43383 has also lost this ability. Strain DSM 15336 is still producing square tablets when cultivated on GTA medium, on plates or broth, at neutral $\mathrm{pH}$ and at temperatures up to $30^{\circ} \mathrm{C}$ (Fig. 1). However, strain DSM 15336 may also lose the tablet-forming ability and produce coccoid cells, in some cases even abnormally enlarged (up to $3.5 \mu \mathrm{m}$ ), under certain conditions, such as when grown on GTA plates or in broth at $37^{\circ} \mathrm{C}$. Interestingly, an identical observation was also reported for ATCC $11041^{\mathrm{T}}$ when it was still able to produce tablet structures (Lany, 1972). A similar loss of the tablet morphology of strain DSM 15336 could also be induced by growth at $30^{\circ} \mathrm{C}$ on either a modified GTA medium (plates or broth) in which acetate

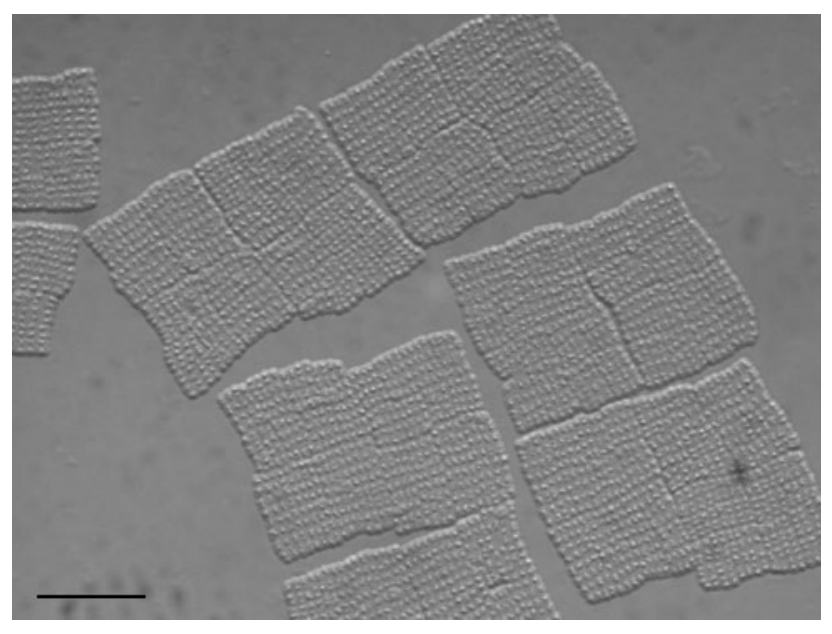

Fig. 1. Bright-field micrograph of cells of Lampropedia hyalina DSM 15336. Bar, $10 \mu \mathrm{m}$.

was replaced by sucrose (GTASuc) or on Luria-Bertani (LB) medium (plates or broth). No such effect was observed when the cells were grown on GTA plates or broth at $\mathrm{pH} 9$. Hybridization of cells of strain DSM 15336 cultivated on GTASuc plates or on LB plates at $30^{\circ} \mathrm{C}$ or on GTA plates at $37^{\circ} \mathrm{C}$ with a fluorescent oligonucleotide probe that targeted Lampropedia hyalina specifically (probe LAMP444; described below) confirmed that all cells were Lampropedia hyalina. Furthermore, when cells of strain DSM 15336 were reinoculated onto GTA plates after cultivation on GTA plates at $37^{\circ} \mathrm{C}$ or on GTASuc plates as well as on LB plates cultivated at $30^{\circ} \mathrm{C}$ and cultivated at $30^{\circ} \mathrm{C}$, they once again produced square tablets, thus indicating clearly that the tablet-forming ability is dependent on the cultivation conditions.

The generation times for strains ATCC $11041^{\mathrm{T}}$, ATCC 43383 and DSM 15336 were $27 \cdot 8,22 \cdot 6$ and $13 \cdot 3$ h, respectively, based on the measurement of cell density by spectrophotometry (Thermo Spectronic Helyos $\alpha$ ) at $620 \mathrm{~nm}$ on cells cultivated in triplicate on GTA broth at $\mathrm{pH} 7 \cdot 2$. Tolerance tests were performed on GTA plates in triplicate at different temperatures $\left(10,20,30,40\right.$ and $\left.50^{\circ} \mathrm{C}\right), \mathrm{pH}$ values $(3,5,6,7,8$ and 9$)$ and sodium chloride concentrations $(1,1.5$ and $2 \%)$. Bile tolerance was determined by addition of $0.5 \%$ bile to GTA medium (plates). Sensitivity against kanamycin $\left(50 \mathrm{mg} \mathrm{l}^{-1}\right)$ was investigated on GTA plates. Production of $\mathrm{N}_{2}$ under anoxic conditions was examined as described by Gerhardt et al. (1994). Cultivation of cells under cyclic anaerobic-aerobic conditions for

\footnotetext{
$\dagger$ This strain has also previously been described to be able to form square tablets of 16 to 64 cells (Austin \& Murray, 1990); however, in this study (also reported by the ATCC, from which it was retrieved), it seems to have lost this ability.

¥Coccoid cells may be produced when grown on GTA medium (plates or broth) at $37^{\circ} \mathrm{C}$ or on other media (at $30^{\circ} \mathrm{C}$ ) such as LB or on GTA medium (plates or broth) where acetate has been replaced by sucrose (GTASuc).

$\S$ Data from other studies are indicated by: $a$, Murray (1984); b, Stante et al. (1997); $c$, Pringsheim (1966); $d$, Hungate (1966). All other data from this study.
} 


\section{Table 1. Summary of differences between three Lampropedia hyalina strains}

All three strains showed similar reactions in the following tests. Negative reactions: Gram-stain; anaerobic growth; nitrate reduction; litmus milk; kanamycin tolerance $\left(50 \mathrm{mg}^{-1}\right)$; acid production from 21 sugar compounds (adonitol, L-arabinose, D-arabitol, cellobiose, dulcitol, erythritol, glucose, inositol, lactose, maltose, D-mannose, D-mannitol, melibiose, methyl D-glucoside, raffinose, rhamnose, salicin, sorbitol, sucrose, trehalose, D-xylose); production of $\mathrm{N}$-acylhomoserine lactone (AHL, PKRC12, PASC8, PSB403); hydrolysis of aesculin, gelatin, $p$-nitrophenyl (pNP) $\beta$-D-galactopyranoside, pNP $\beta$-D-glucuronide, pNP $\alpha$-D-glucopyranoside, pNP $\beta$-D-glucopyranoside, pNP $\beta$-D-xylopyranoside, pNP phenylphosphonate, pNP phosphorylcholine, 2-deoxythymidine-5'-pNP phosphate, L-alanine $p$-nitroanilide (pNA), L-glutamate$\gamma$-3-carboxy pNA, L-proline pNA, starch and urea; and assimilation of $N$-acetyl-D-galactosamine, $N$-acetyl-D-glucosamine, L-arabinose, p-arbutin, D-cellobiose, D-fructose, D-galactose, gluconate, D-glucose, D-mannose, D-maltose, $\alpha$-D-melibiose, L-rhamnose, D-ribose, sucrose, salicin, D-trehalose, D-xylose; adonitol, i-inositol, maltitol, D-mannitol, D-sorbitol; cis-aconitate, trans-aconitate, adipate, azelate, citrate, itaconate, mesaconate, oxoglutarate, suberate; L-alanine, $\beta$-alanine, L-histidine, L-leucine, L-ornithine, L-phenylalanine, L-proline, L-serine, L-tryptophan, 3-hydroxybenzoate and phenylacetate. Positive reactions: growth on GTA medium, LB medium and R2A medium; lipid inclusions (analysed by the Sudan black stain); catalase; oxidase; $\mathrm{NaCl}$ tolerance $1.5 \%$; $\mathrm{pH}$ tolerance $6-9$; temperature tolerance $10-40{ }^{\circ} \mathrm{C}$; and assimilation of acetate, DL-3-hydroxybutyrate and propionate. ND, Not determined.

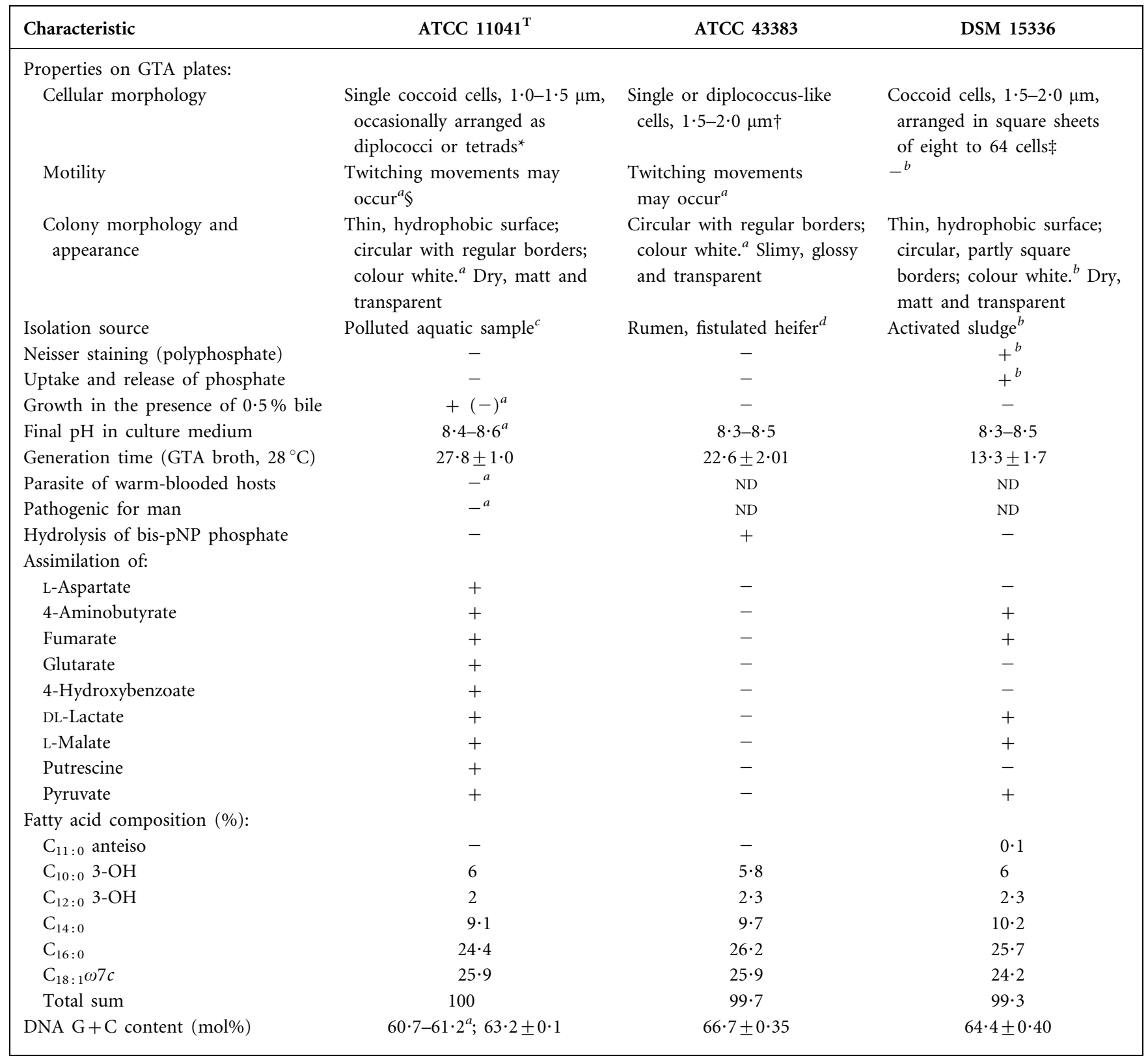

* Original description: sheets of rounded, almost cubical cells, arranged in square tablets of 16 to 64 cells. However, this strain has mutated and grows now only as single or clustered coccoid cells (Murray, 1963). 
stimulation of polyphosphate accumulation was performed as described by Stante et al. (1997). Two other standard media, LB plates and R2A plates (Reasoner \& Geldreich, 1985), were also used to test whether these media supported growth of Lampropedia. All tests were followed for up to 7 days. Tests for oxidase, catalase and litmus milk were performed as described by Gerhardt et al. (1994). Metabolic fingerprinting (Table 1) was performed by using the miniaturized assay method described by Kämpfer et al. (1991). Hydrolysis of gelatin, starch and urea were examined as described by Gerhardt et al. (1994).

In summary, the three Lampropedia strains were strongly similar in terms of general phenotypic characteristics (Table 1). The major differences observed among the three strains were in the ability to accumulate polyphosphate under anaerobic-aerobic cyclic incubation conditions (Stante et al., 1996, 1997), bile tolerance (albeit weakly), the ability to hydrolyse one compound (out of 16 tested), bis-p-nitrophenyl phosphate, and some minor differences in assimilation of different substrates. Furthermore, growth measurements on GTA broth (containing acetate, one of the three compounds that could be assimilated by all three strains; Table 1) showed that the rate of utilization of acetate [analysed as acetic acid by GC (DANI 8510) as described by Stante et al., 1997] differed significantly between the three strains. DSM 15336 showed the highest rate of utilization (results not shown).

The composition of fatty acids was determined as described by Kämpfer et al. (2003) on cells grown on nutrient agar plates with $1 \%(\mathrm{w} / \mathrm{v})$ sodium acetate and on GTA plates at $28^{\circ} \mathrm{C}$. The three strains showed nearly identical fatty acid compositions. The main fatty acid methyl ester components detected were $\mathrm{C}_{10: 0} 3-\mathrm{OH}(5 \cdot 8-6 \%), \mathrm{C}_{12: 0} 3-\mathrm{OH}$ $(2-2 \cdot 3 \%), \mathrm{C}_{14: 0}(9 \cdot 1-10 \cdot 7 \%), \mathrm{C}_{16: 0}(24 \cdot 4-26 \cdot 2 \%)$ and $\mathrm{C}_{18: 1} \omega 7 c(24 \cdot 2-25 \cdot 9 \%)$. The presence of $\mathrm{C}_{10} 3-\mathrm{OH}$ and $\mathrm{C}_{12}$ $3-\mathrm{OH}$ has also been reported for other members of the Comamonadaceae (Wen et al., 1999; Spring et al., 2004).

Analysis of the production by the Lampropedia strains of three different quorum-sensing $\mathrm{N}$-acylhomoserine lactone molecules, PKRC12, PASC8 and PSB404, representative for some betaproteobacteria, was performed as described by Steidle et al. (2002). However, none of the strains produced any of the $\mathrm{N}$-acylhomoserine lactone molecules investigated (Steidle et al., 2002).

Genomic DNA was extracted and purified for further molecular analyses, as described by Ziemke et al. (1998). For subsequent sequencing of the $16 \mathrm{~S}$ rRNA gene, almost complete 16S rRNA gene fragments were amplified from DNA by using the primers 27F and 1492R (Lane, 1991). For $16 \mathrm{~S}$ rRNA gene amplification, reaction mixtures (total volume, $50 \mu \mathrm{l}$ ) containing $20 \mathrm{ng}$ DNA template and each primer at a concentration of $25 \mathrm{pM}$ were prepared by adding $20 \mathrm{mM} \mathrm{MgCl}_{2}$ reaction buffer (Idaho Technology) and $2.5 \mathrm{U}$ Taq DNA polymerase (Promega). Thermal cycling was carried out by using an initial denaturation step of $94^{\circ} \mathrm{C}$ for $1 \mathrm{~min}$, followed by 30 cycles of denaturation at $94{ }^{\circ} \mathrm{C}$ for $40 \mathrm{~s}$, annealing at $50^{\circ} \mathrm{C}$ for $40 \mathrm{~s}$ and elongation at $72^{\circ} \mathrm{C}$ for $90 \mathrm{~s}$. Cycling was completed by a final elongation step of $72{ }^{\circ} \mathrm{C}$ for $10 \mathrm{~min}$. Prior to sequencing, PCR products were purified by means of the QIAquick PCR purification kit (Qiagen). Nucleotide sequences were determined by the sequencing protocol from Epicenter Technologies (Biozyme). The new 16S rRNA gene sequences ( $>1400 \mathrm{nt},<0.5 \%$ ambiguity) were added to an alignment of about 50000 small-subunit rRNA sequences by using the alignment tool of the ARB program package (Ludwig et al., 2004). Alignments were refined by visual inspection. Phylogenetic analyses were performed by using distance-matrix, parsimony and maximum-likelihood (AXML in the ARB software) methods. Various datasets comparing different selections of sequences and alignment positions were used (Ludwig et al., 1998). The three Lampropedia strains used in this study showed strong similarity $(98 \cdot 8-99 \cdot 8 \%)$ to each other at the 16S rRNA gene level. Further sequence comparison with three additional Lampropedia hyalina 16S rRNA gene sequences available on the NCBI public database (http://www.ncbi. nlm.nih.gov/; accession numbers AB086632, AB092691 and AB089485), previously placed within the 'Gammaproteobacteria' (Pseudomonadaceae) (Bergey's taxonomic outline, July 2002) but recently moved to the 'Betaproteobacteria' (Bergey's taxonomic outline, October 2003; Xie et al., 2003), showed strong similarity to the strains in this study (e.g. 99.8 \% $16 \mathrm{~S}$ rRNA gene similarity to the type strain ATCC $\left.11041^{\mathrm{T}}\right)$. All Lampropedia hyalina strains form a distinct group among the 'Betaproteobacteria', showing 94.6-93\% $16 \mathrm{~S}$ rRNA gene sequence similarity to members of various genera such as Acidovorax, Aquaspirillum, Brachymonas, Comamonas, Delftia and Xenophilus. The closest cultured relative is most likely Brachymonas denitrificans (94.6\% 16S rRNA gene sequence similarity), as suggested by distance matrix, parsimony and maximum-likelihood treeing methods (Fig. 2).

Determination of the $\mathrm{G}+\mathrm{C}$ content and DNA-DNA reassociation experiments were carried out as described by Ziemke et al. (1998). The G $+C$ contents of strains ATCC $11041^{\mathrm{T}}$, ATCC 43383 and DSM 15336 were respectively $63.2 \mathrm{~mol} \%$ [slightly higher in comparison with the preliminary result of around $60 \mathrm{~mol} \%$ cited by Murray (1984)], 66.7 and $64 \cdot 4 \mathrm{~mol} \%$. DNA-DNA reassociation studies showed a relatively higher reassociation between DSM 15336 and ATCC $11041^{\mathrm{T}}(94 \cdot 7 \%$, SD $0.6 \%)$ than between ATCC $11041^{\mathrm{T}}$ and ATCC $43383(90 \cdot 4 \%$, SD $0 \cdot 6 \%)$. These data indicate clearly that all three strains can be classified within the same species, Lampropedia hyalina.

For culture-independent identification of Lampropedia hyalina by means of fluorescent in situ hybridization, cells were fixed in exponential phase in $4 \%(\mathrm{w} / \mathrm{v})$ paraformaldehyde for $3 \mathrm{~h}$ at $4{ }^{\circ} \mathrm{C}$, as described by Amann (1995). In situ hybridization of the samples with oligonucleotides labelled with the monofunctional, hydrophilic, sulfoindocyanine 


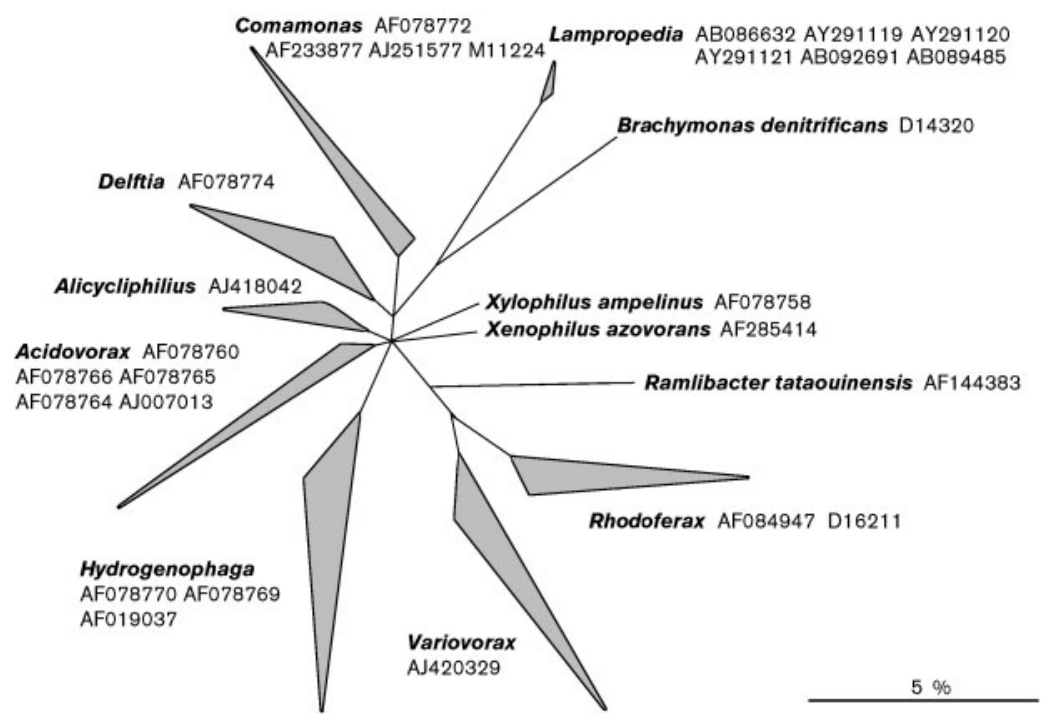

Fig. 2. $16 \mathrm{~S}$ rRNA gene-based tree reflecting the relationships of Lampropedia hyalina and selected representatives of the Comamonadaceae. The tree topology is based upon the results of a maximum-parsimony analysis (ARB_parsimony; Ludwig et al., 2004) of 28277 at-least $90 \%$ complete small-subunit rRNA gene primary structures and was corrected according to data obtained by applying alternative treeing approaches. Alignment positions variable in more that $50 \%$ of all available $16 \mathrm{~S}$ rRNA gene sequences from representatives of the Comamonadaceae were excluded from the calculations. Multifurcations indicate that a common stable branching order was not significantly supported applying different treeing methods on various datasets. Phylogenetic groups are indicated by triangles. Accession numbers are given for the respective type strains. Bar, $5 \%$ estimated sequence divergence. dye Cy3 (purchased from Interactiva) was performed as described by Amann (1995). Samples subjected to fluorescent in situ hybridization were mounted with Citifluor and viewed using a model LSM 510 scanning confocal microscope (Carl Zeiss) equipped with a UV laser (351 and $364 \mathrm{~nm}$ ), an $\mathrm{Ar}$ ion laser (450 to $514 \mathrm{~nm}$ ) and two $\mathrm{HeNe}$ lasers (543 and $633 \mathrm{~nm}$ ). Different probes were used for identification of Lampropedia hyalina. For confirmation of the phylogenetic position among the 'Betaproteobacteria', two general probes targeting the betaproteobacteria on the 23S rRNA gene level (BET42a; Manz et al., 1992) and on the 16S rRNA gene level (BONE, together with the competitor for BTWO; Amann et al., 1996) were used. All three investigated Lampropedia hyalina strains yielded bright signals with these probes. Probes that target Lampropedia hyalina specifically were also developed. Probe design was performed on the basis of 50000 complete and partial 16S rRNA gene sequences present in the ARB database (http:// www.arb-home.de) and updated (January 2004) with all relevant existing sequences of Lampropedia hyalina and close relatives. Three specific probes were selected on the basis of the 16S rRNA gene sequence: LAMP114 (5'CGTTCCGATGTCTTACTC-3'), LAMP444 (5' -CCCAGTCCTTTTCGTTCT-3') and LAMP1017 (5'-TCTTTCGAGCACAATCCC- $\left.3^{\prime}\right)$. Optimization of the hybridization conditions for these probes was performed by hybridizing at different formamide concentrations, ranging from 0 to $60 \%$, and determining the optimal signal intensity visually by microscopy (quantitative single-cell signal intensity measurement was not possible due to the tablet clusters of DSM 15336). The Lampropedia strains investigated in this study showed no autofluorescence and showed significant hybridization signals with probes LAMP114 and LAMP444 in the absence of formamide. No signals were obtained with probe LAMP1017 in the absence of formamide, which indicates that this target region is inaccessible. Different optimal hybridization conditions were observed for probes LAMP114 and LAMP444 for the three Lampropedia strains. Probe LAMP114 yielded strong hybridization signals at a formamide concentration up to $10 \%$ with the two strains ATCC $11041^{\mathrm{T}}$ and ATCC 43383 and up to $30 \%$ with DSM 15336. Probe LAMP444 yielded strong hybridization signals at a formamide concentration up to $40 \%$ with all three strains. Hybridization with probes LAMP114 and LAMP444 with members of two distantly related genera among the 'Betaproteobacteria', Comamonas testosteroni and Hydrogenophaga flava, in the absence of formamide yielded no signals.

\section{Considerations regarding the taxonomy of Lampropedia hyalina ATCC $11041^{\top}$}

This study shows clearly that the two investigated strains of Lampropedia hyalina from the ATCC (ATCC $11041^{\mathrm{T}}$ and ATCC 43383) and Lampropedia sp. DSM 15336 are strongly similar in terms of general physiological, chemotaxonomic and molecular characteristics (Table 1), despite differences in morphology and isolation source. They thus belong to the same species, according to the directions of Stackebrandt et al. (2002). The tablet morphology should not be decisive for the species description and thus is also not an argument for the declaration of a neotype strain for Lampropedia hyalina, as suggested by Murray (1984). Tablet morphology is unique in nature, but has nevertheless been observed in two other genera, representing entirely different physiological lifestyles: the anaerobic, sulfur-oxidizing Thiopedia [16S rRNA gene phylogenetic position unknown (Pfennig, 1989); possibly 'Gammaproteobacteria' (Bergey's taxonomic outline, October 2003)] and the photosynthetic Merismopedia (cyanobacteria), which has also been reported 
to lose its tablet morphology under certain conditions (Palinska et al., 1996). Furthermore, the ability of DSM 15336 to accumulate polyphosphate, under cyclic aerobicanaerobic conditions, in contrast to the other two investigated strains, does not present a strong enough argument for the declaration of a distinct subspecies. For example, polyphosphate-accumulating Acinetobacter strains have also been isolated from activated sludge but, despite thorough taxonomic comparison of these strains with non-polyphosphate-accumulating Acinetobacter strains, a further subspecies division of these strains could not be made on the basis of this capacity (Kämpfer et al., 1992). On the basis of the results generated in this study, emended descriptions of the genus Lampropedia and the species Lampropedia hyalina are presented.

\section{Emended description of the genus Lampropedia Schroeter 1886}

Based on the properties given in the genus description by Murray (1984), members of the genus Lampropedia are coccoid species, able under certain conditions to form square tablets of eight to 64 cells, occasionally separated into pairs or tetrads. Their DNA G $+\mathrm{C}$ content is between 63 and $67 \mathrm{~mol} \%$ and their fatty acid profile consists of $\mathrm{C}_{10: 0}$ $3-\mathrm{OH}, \mathrm{C}_{12: 0} 3-\mathrm{OH}, \mathrm{C}_{14: 0}, \mathrm{C}_{16: 0}$ and $\mathrm{C}_{18: 1} \omega 7 \mathrm{c}$. Assimilation of acetate, DL-3-hydroxybutyrate and propionate. Closest cultured relative is Brachymonas denitrificans (94.6\% $16 \mathrm{~S}$ rRNA gene similarity). The type species is Lampropedia hyalina.

\section{Emended description of Lampropedia hyalina (Ehrenberg 1832) Schroeter 1886}

In addition to the properties given in the genus description above, members of the species may share some minor additional phenotypic characteristics listed in Table 1. To date, only three strains of Lampropedia hyalina have been characterized: the type strain $\left(\right.$ ATCC $11041^{\mathrm{T}}=$ CCUG $48573^{\mathrm{T}}=$ DSM $16112^{\mathrm{T}}$ ), isolated from polluted water (Pringsheim, 1966); strain ATCC 43383 (=CCUG 48574), isolated from the rumen of a fistulated heifer (Hungate, 1966); and strain DSM 15336 (=CCUG 48575), isolated from activated sludge (Stante et al., 1997). The type strain and strain ATCC 43383 have apparently lost the ability to form tablet structures, whereas DSM 15336 is still able to form tablet structures. Despite this difference in morphology, their different isolation sources and some minor phenotypic differences (Table 1), all three strains show high DNA-DNA reassociation (90-95\%) and high $16 \mathrm{~S}$ rRNA gene sequence similarity ( $>98 \%$ ).

The type strain is strain ATCC $11041^{\mathrm{T}}$ (=CCUG $48573^{\mathrm{T}}$ $=$ DSM $16112^{\mathrm{T}}$ ).

\section{Acknowledgements}

The following colleagues are acknowledged: Dr F. Malaspina and Dr S. Gemelli for a precious collaboration; Dr A. Tilche, European Commission (Key Action 'Sustainable Management and Quality of
Water'), Dr G. Bortone, Servizio Tutela e Risanamento Risorsa Acqua, Regione Emilia Romagna, and Dr M. Wagner, University of Vienna, for encouragement of this work; Dr K. Riedel and Dr A. Steidle, Lehrstuhl für Mikrobiologie, Technische Universität München, for analysis of $\mathrm{N}$-acylhomoserine lactone signal molecules; and M. Valens, Grup d'Oceanografia Interdisciplinari Institut Mediterrani d'Estudis Avançats, Spain, for technical assistance.

\section{References}

Amann, R. (1995). In situ identification of micro-organisms by whole cell hybridization with rRNA-targeted nucleic acid probes. In Molecular Microbial Ecology Manual, pp. 3.3.6.1-3.3.6.15. Edited by A. D. L. Akkermanns, J. D. van Elsas \& F. J. de Brujin. Dordrecht: Kluwer Academic.

Amann, R., Snaidr, J., Wagner, M., Ludwig, W. \& Schleifer, K.-H. (1996). In situ visualization of high genetic diversity in a natural microbial community. J Bacteriol 178, 3496-3500.

Austin, J. W. \& Murray, R. G. E. (1990). Isolation and in vitro assembly of the components of the outer S layer of Lampropedia hyalina. J Bacteriol 172, 3681-3689.

Gerhardt, R., Murray, R. G. E., Wood, W. A. \& Krieg, N. R. (editors) (1994). Methods for General and Molecular Bacteriology. Washington, DC: American Society for Microbiology.

Hungate, R. E. (1966). The Rumen and its Microbes. New York: Academic Press.

Kämpfer, P., Steiof, M. \& Dott, W. (1991). Microbiological characterization of a fuel oil contaminated site including numerical identification of heterotroph water and soil bacteria. Microb Ecol 21, 227-251.

Kämpfer, P., Bark, K., Busse, H.-J., Auling, G. \& Dott, W. (1992). Numerical and chemotaxonomy of polyphosphate accumulating Acinetobacter strains with high polyphosphate: AMP phosphotransferase (PPAT) activity. Syst Appl Microbiol 15, 409-419.

Kämpfer, P., Dreyer, U., Neef, A., Dott, W. \& Busse, H.-J. (2003). Chryseobacterium defluvii sp. nov, isolated from wastewater. Int J Syst Evol Microbiol 53, 93-97.

Lane, D. J. (1991). 16S/23S rRNA sequencing. In Nucleic Acid Techniques in Bacterial Systematics, pp. 115-175. Edited by E. Stackebrandt \& M. Goodfellow. Chichester: Wiley.

Lany, S. G. (1972). Morphological studies of cell envelope differences among colony variants of Lampropedia hyalina. MSc thesis, University of Western Ontario, London, Ontario, Canada.

Ludwig, W., Strunk, O., Klugbauer, S., Klugbauer, N., Weizenegger, M., Neumaier, J., Bachleitner, M. \& Schleifer, K. H. (1998). Bacterial phylogeny based on comparative sequence analysis. Electrophoresis 19, 554-568.

Ludwig, W., Strunk, O., Westram, R. \& 29 other authors (2004). ARB: a software environment for sequence data. Nucleic Acids Res 32, 1363-1371.

Manz, W., Amann, R., Ludwig, W., Wagner, M. \& Schleifer, K.-H. (1992). Phylogenetic oligonucleotide probes for the major subclasses of Proteobacteria: problems and solutions. Syst Appl Microbiol 15, 593-600.

Murray, R. G. E. (1963). Role of superficial structures in the characteristic morphology of Lampropedia hyalina. Can J Microbiol 9, 593-600.

Murray, R. G. E. (1984). Genus Lampropedia Schroeter 1886, $151^{\mathrm{AL}}$. In Bergey's Manual of Systematic Bacteriology, vol. 1, pp. 402-406. Edited by N. R. Krieg \& J. G. Holt. Baltimore: Williams \& Wilkins.

Palinska, K. A., Liesack, W., Rhiel, E. \& Krumbein, W. E. (1996). Phenotype variability of identical genotypes: the need for a 
combined approach in cyanobacterial taxonomy demonstrated on Merismopedia-like isolates. Arch Microbiol 166, 224-233.

Pfennig, N. (1989). Genus IX. Thiopedia Winogradsky $1888,85^{\mathrm{AL}}$. In Bergey's Manual of Systematic Bacteriology, vol. 3, pp. 1652-1653. Edited by J. T. Staley, M. P. Bryant, N. Pfennig \& J. G. Holt. Baltimore: Williams \& Wilkins.

Pringsheim, E. G. (1966). Lampropedia hyalina Schroeter, eine apochlorotische Merismopedia (Cyanophyceae). Arch Mikrobiol 55, 200-208 (in German).

Reasoner, D. J. \& Geldreich, E. E. (1985). A new medium for the enumeration and subculture of Bacteria from potable water. Appl Environ Microbiol 49, 1-7.

Schroeter, J. (1886). In Kryptogamenflora von Schlesien, Bd. 3, Heft 3, Pilze. Edited by F. Cohn. Breslau: J. U. Kern's Verlag.

Spring, S., Jäckel, U., Wagner, M. \& Kämpfer, P. (2004). Ottowia thiooxydans gen. nov., sp. nov., a novel facultatively anaerobic, $\mathrm{N}_{2} \mathrm{O}-$ producing bacterium isolated from activated sludge, and transfer of Aquaspirillum gracile to Hylemonella gracilis gen. nov., comb. nov. Int J Syst Evol Microbiol 54, 99-106.

Stackebrandt, E., Frederiksen, W., Garrity, G. M. \& 10 other authors (2002). Report of the ad hoc committee for the re-evaluation of the species definition in bacteriology. Int J Syst Evol Microbiol 52, 1043-1047.
Stante, L., Cellamare, C. M., Malaspina, F., Bortone, G. \& Tilche, A. (1996). Production of poly-beta hydroxybutyrate by Lampropedia sp. isolated from activated sludge for phosphorus removal. Med Fac Landbouww Univ Gent 61/4b, 2101-2108.

Stante, L., Cellamare, C. M., Malaspina, F., Bortone, G. \& Tilche, A. (1997). Biological phosphorus removal by pure culture of Lampropedia spp. Water Res 31, 1317-1324.

Steidle, A., Allesen-Holm, M., Riedel, K., Berg, G., Givskov, M., Molin, S. \& Eberl, L. (2002). Identification and characterization of an $N$-acylhomoserine lactone-dependent quorum-sensing system in Pseudomonas putida strain IsoF. Appl Environ Microbiol 68, 6371.

Wen, A., Fegan, M., Hayward, C., Chakraborty, S. \& Sly, L. I. (1999). Phylogenetic relationships among members of the Comamonadaceae, and description of Delftia acidovorans (den Dooren de Jong 1926 and Tamaoka et al. 1987) gen. nov., comb. nov. Int J Syst Bacteriol 49, 567-576.

Xie, C. H. \& Yokota, A. (2003). Phylogenetic analyses of Lampropedia hyalina based on the 16S rRNA sequence. J Gen Appl Microbiol 49, 345-349.

Ziemke, F., Höfle, M. G., Lalucat, J. \& Rosselló-Mora, R. (1998). Reclassification of Shewanella putrefaciens Owen's genomic group II as Shewanella baltica sp. nov. Int J Syst Bacteriol 48, 179-186. 